\title{
Performance evaluation for Bioethanol production in three reactors: Batch, packed bed and Fluidized bed bio-reactors
}

\author{
B.S.V.S.R. Krishna*1, Umesh Kumar Kakadiya², \\ $1^{\star}$ Associate Professor, Department of Chemical Engineering, MIT, Manipal University, \\ Manipal-576104, India, krishna.bandaru@manipal.edu \\ 2 M Tech Student, MIT, Manipal-576104, India. umesh.kakadiya89@gmail.com
}

\begin{abstract}
Ethanol demand has continued to grow, both as an alternative fuel and as a petroleum fuel extender because of gasoline shortages. Ethanol production from renewable carbohydrate materials has attracted worldwide interest, and much research has focused on ethanol production using immobilized viable microbial cells in continuous systems. Biochemical pathway, the main reactor used for fermentation is classical well-mixed reactor need to be improved to the continuous reactor to reduce the operation cost, product inhibition and wash out. Immobilized biomass (Saccharomyces cerevisiae) activity has been given more attention, since it has been acknowledged to play a significant role in bioreactor performance. An attempt has been made to compare the production of bioethanol in batch, packed, fluidized bed bio-reactors. Present study, focused mainly sodium alginate (2\% to $6 \%$ ) as micro-organism support for production of bio-ethanol in all three reactors and find the better reactor and better concentration of sodium alginate for immobilization of yeast.
\end{abstract}

Key words: Ethanol, Saccharomyces cerevisiae, Bioethanol, Bio-reactor,. Micro-organism.

\section{INTRODUCTION}

Bio-Ethanol demand has continued to grow, both as an alternative fuel and as a petroleum fuel extender because of gasoline shortages. Ethanol production from renewable carbohydrate materials has attracted worldwide interest, and much research has focused on ethanol production using immobilized viable microbial cells in continuous systems (Bangrak, et al. (2009)). Fermentation is a process to convert these

carbohydrates (sugars) to ethanol. The fermentation reaction is done by the yeast or bacteria, which feed with sugar. As the reaction proceed, sugar is consumed by yeast and ethanol and carbon dioxide is produced by following reaction.

$$
\begin{aligned}
& \mathrm{C}_{6} \mathrm{H}_{12} \mathrm{O}_{6} \text { (glucose) } \\
& 2 \mathrm{CH}_{3} \mathrm{CH}_{2} \mathrm{OH} \text { (ethanol) }+2 \mathrm{CO}_{2} \text { (carbon } \\
& \text { dioxide) }
\end{aligned}
$$

In addition the use of bioethanol is generally $\mathrm{CO}_{2}$ neutral, because in the growing phase of the source crop, $\mathrm{CO}_{2}$ is absorbed by the plant and oxygen is released in the same volume that $\mathrm{CO}_{2}$ is produced in the combustion of the bioethanol. This creates an obvious advantage over fossil fuels which only emit $\mathrm{CO}_{2}$ as well as other poisonous emissions (Mariam et al. (2009)). Ethanol can be blended with petrol for transportation purpose. Compared to single gasoline, ethanol has a higher octane number (96113) that reduce the need for toxic octane enhancing additives. It is also a provider of oxygen which helps to reduce the emission of carbon monoxide, nitrogen oxide, non-combusted hydrocarbon and volatile organic compound after combustion (Hossain et al. (2009)). In addition, ethanol is about $15 \%$ more efficient than gasoline in optimized spark ignition engine (Hossain et al. (2009)). Ethanol blended fuels are widely sold in the United States and Brazil. The Brazilian car manufacturing industry developed flexible fuel vehicles that can run on hydrous ethanol $(100 \%$ ethanol or E100). The production of bioethanol as an alternative fuel by fermentation of sugar has been increasing due to the increasing demands, which is expected to produce high and good yield of ethanol (Zain et al. (2009)

\section{MATERIALS AND METHODS}

Schematic diagram of experimental setups were shown in Fig $1 \mathrm{a}, 1 \mathrm{~b}$ and $1 \mathrm{c}$ and named as batch reactor, fluidized bed reactor and packed bed reactor respectively. The experimental setup consists of following sections i.e. test section with sodium alginate beads, pumps, stock solution and product (bioethanol) for fluidized and packed reactors while the batch reactor consists three necked $2000 \mathrm{ml}$ round bottom flask. Two peristaltic pumps were used to meet the pumping requirements and were connected to the inlet of the reactor using a T-joint. A bed of glass beads was used as a base support for the sodium alginate particles for fluidized bed bioreactor while the 
packed bed had a support of mesh at bottom and bottom of the reactor.

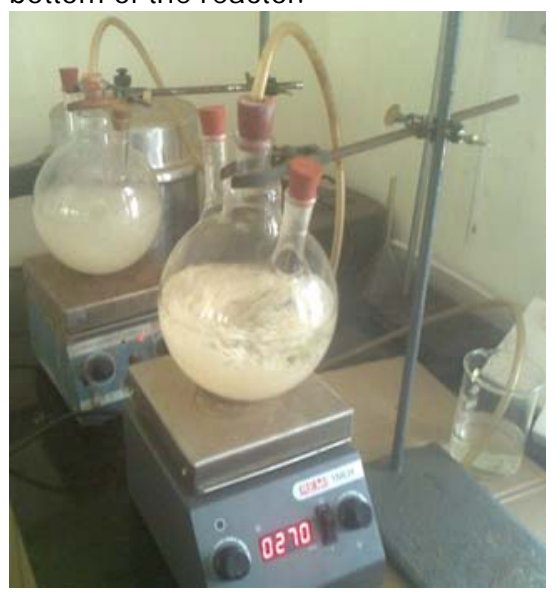

Fig $1 \mathrm{a}$

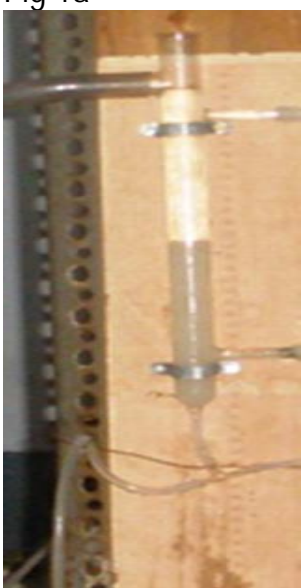

Fig $1 b$

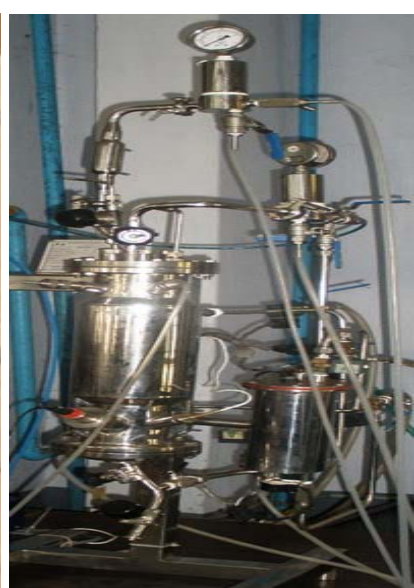

Fig $1 \mathrm{c}$
Fig 1a,1b,1c: Schematic diagram of experimental setup namely Batch reactor, Fluidized bioreactor, Packed bed bioreactor respectively.

\section{A. Preparation of sodium alginate beads and estimation of ethanol: \\ Sodium alginate solution was prepared by} slowly dispersing the sodium alginate powder $(2 \%$, $4 \%$ and $6 \%$ by weight) in distilled water in a continuously stirring beaker. The sodium alginate solution and prepared Saccharomyces cerevisiae cell suspension was mixed suitably to make a uniform solution, these solution was added dropwise to the $2 \% \mathrm{CaCl}_{2}$ solution using a pre-calibrated syringe. Calibration of syringe was done by weighing the drop weight using a balance. The drops formed as soft beads. The beads are allowed to harden in the $\mathrm{CaCl}_{2}$ solution and washed with saline solution to clean the excess calcium ions. The immobilized bead size was measured by using the electronic microscope. The immobilized beads are stored at $4{ }^{\circ} \mathrm{C}$ until use (Zain et al. (2009)). A detailed explanation for preparation was given elsewhere (Das et. al. (2014), Goksungur and Zorlu (2009)).

\section{EXPERIMENTAL PROCEDURE}

The experimental setup of Batch reactor, Fluidized bed bio reactor and Packed bed bioreactor were rinsed with distilled water followed by ethanol. These reactors were sterilized using steam for 15 min and filled with equal number/weight of particles. Special consideration was taken in case of batch reactor to leave half of the volume as empty space. Magnetic stirrer was used for mixing purpose in Batch reactor while sparging of air was used in packed bed bioreactor. The sterilized glucose $(8 \%$ by wt.) was used as feed for the reactors. The favourable $\mathrm{pH}$ for fermentation procedure is 3.5 to 5.5 (Goksungur and Zorlu (2009)) while present study has chosen $\mathrm{pH}$ with 4.2 to 4.5 as an intermediate value. The $\mathrm{pH}$ was maintained using dilute sulphuric acid or sodium hydroxide solution. The calibrated peristaltic pumps were used to pump the glucose to the reactors. Proper arrangements were made for collecting the product. The samples were collected at regular intervals and analysed the samples for glucose and ethanol. The flow rate was maintained at above minimum fluidization velocity and below terminal velocity of the particles used in the fluidized bed bioreactor. The two flow reactors were filled with $75 \%$ of volume with yeast immobilized sodium alginate beads. Same procedure was repeated for $2 \%, 4 \%$ and $6 \%$ sodium alginate particles. Approximately $5 \mathrm{~L}$ glucose solution was kept as feed reservoir for packed bed and fluidized bed bio reactors separately and $1 \mathrm{~L}$ glucose solution for batch reactor. The glucose solution was recirculated in packed and fluidized bed reactors with yeast immobilized sodium alginate beads. At regular intervals the samples were collected from the solution and analyzed for ethanol and glucose solution (Selvaraj and Krishna (2012)). The experiments were conducted for $120 \mathrm{hrs}$. All the experiments were conducted at room temperature and pressure.

\section{B.Glucose assay}

Chemicals and reagents: Phenol 5\%:

1) Weigh $5 \mathrm{gm}$ of phenol crystals in measuring jar and melt in a water bath at $60^{\circ} \mathrm{C}$.

2) Make up the $100 \mathrm{ml}$ with distilled water in volumetric flask and store in a dark glass bottle.

Stock solution Preparation: 1) Glucose stock 0.1\%: Weigh $50 \mathrm{mg}$ of D-Glucose accurately into a $50 \mathrm{ml}$ 
standard volumetric flask, dissolve in HPLC grade or equivalent water make up the volume.

2) Take $1 \mathrm{ml}$ of above stock solution in to $10 \mathrm{ml}$ volumetric flask; make up the volume till the mark with HPLC grade or equivalent water $(100 \mu \mathrm{g} / \mathrm{ml})$.

Using Spectrophotometer the glucose concentration was measured at $490 \mathrm{~nm}$.

Ethanol assay

Acid dichromate solution: (0.01 molL-1in 5.0 molL1sulfuric acid) $125 \mathrm{ml}$ of water was added to a 500 $\mathrm{ml}$ conical flask. Carefully $70 \mathrm{ml}$ of concentrated sulphuric acid was added with constant swirling. Flasks were cooled under cold water tap and $0.75 \mathrm{~g}$ of potassium dichromate was added. It was then diluted to $250 \mathrm{ml}$ with distilled water.

Starch indicator solution (1.0\% (w/v) solution) $1.0 \mathrm{~g}$ of soluble starch was dissolved in $100 \mathrm{ml}$ of recently boiled water. The mixture was stirred until dissolved.

Sodium thiosulfate solution (0.03molL-1) - $7.44 \mathrm{~g}$ of $\mathrm{Na}_{2} \mathrm{~S}_{2} \mathrm{O}_{3} .5 \mathrm{H}_{2} \mathrm{O}$ was added to a $1 \mathrm{~L}$ volumetric flask, dissolved in distilled water and diluted up to the mark.

Potassium iodide solution: (1.2molL-1) - $5 \mathrm{~g}$ of KI was dissolved in $25 \mathrm{ml}$ of water.

Titration Procedurev

Sample is diluted at 1:20 with distilled water and separately $10 \mathrm{ml}$ of the acid dichromate solution was transferred to a $250 \mathrm{ml}$ conical flask with rubber stopper.

$1 \mathrm{ml}$ of the diluted sample was pipetted into the sample holder. Three samples of the beverage were prepared as the entire contents of the flask are used in the titration.

The sample holder was suspended over the dichromate solution and held in place with the rubber stopper and flask was stored overnight at $25-30^{\circ} \mathrm{C}$

Next morning the flask was allowed to come to room temperature, then loosened the stopper and carefully removed and discarded the sample holder.

The walls of the flask were rinsed with distilled water, and then about $100 \mathrm{ml}$ of distilled water was added along with $1 \mathrm{ml}$ of potassium iodide solution. The mixture was swirled to mix properly.

Blank titrations were prepared by adding $10 \mathrm{ml}$ of acid dichromate solution to a conical flask, adding $100 \mathrm{ml}$ of water and $1 \mathrm{ml}$ of potassium iodide solution and swirling to mix.

The burette was filled with sodium thiosulfate solution and each flask was titrated with sodium thiosulfate. When the brown iodine colour faded to yellow, $1 \mathrm{ml}$ of starch solution was added and was further titrated until the blue colour disappeared. The blank flasks were titrated first, and repeated until concordant results were obtained. Then each of the samples was titrated till the concordant results, further samples will need to be prepared.

\section{RESULTS AND DISCUSSION}

Fig 2 shows the variation of glucose and ethanol concentration with time in batch reactor. The glucose concentration gradually reduced and ethanol concentration gradually increased with time for all reactor setups as observed in literature (Chuichulcherm (2005), Goksungur and Zorlu (2009)). Similar behavior was observed in other two reactors. The microorganism will consume the sugar and converts as ethanol.

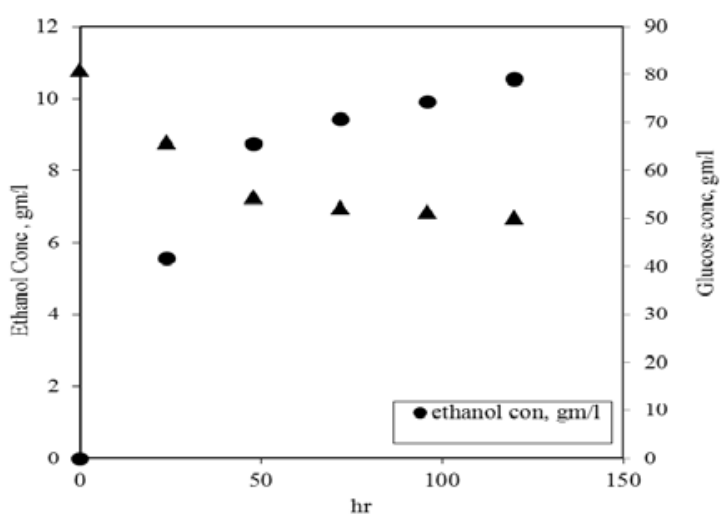

Fig 2 shows the variation of glucose and ethanol concentration with time in batch reactor.

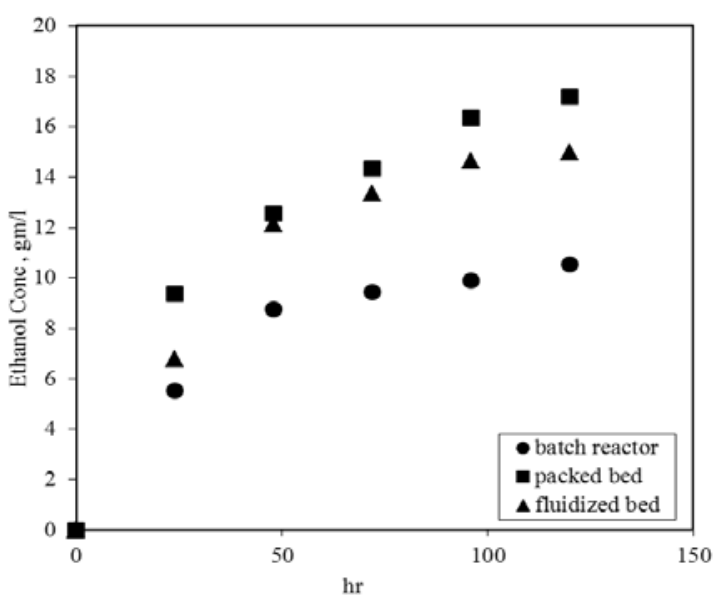

Fig 3 comparision of ethanol production with $2 \%$ sodium alginate yeast immobilized beads. 


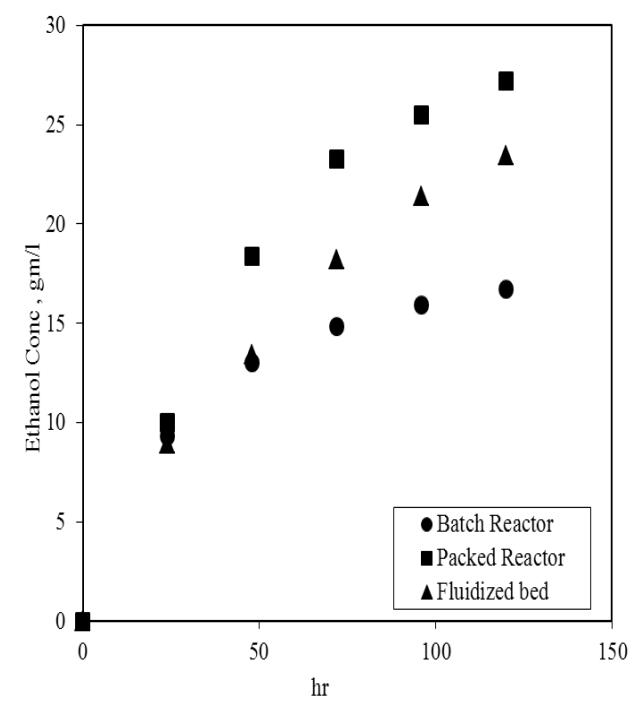

Fig4 comparision of ethanol production with $4 \%$ sodium alginate yeast immobilized beads.

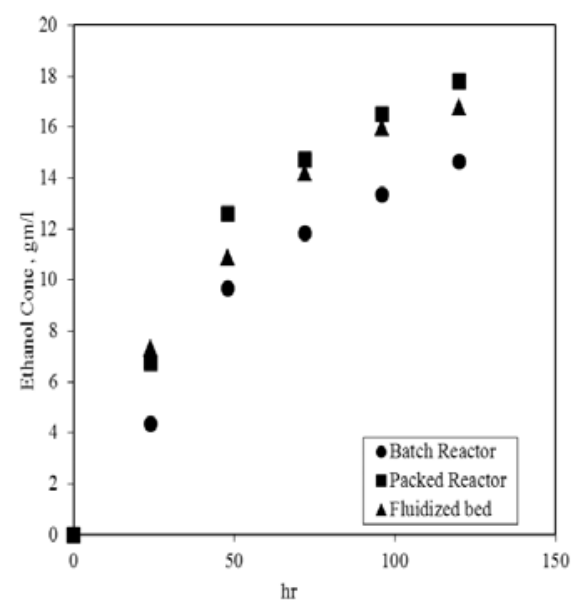

Fig5 comparision of ethanol production with $6 \%$ sodium alginate yeast immobilized beads.

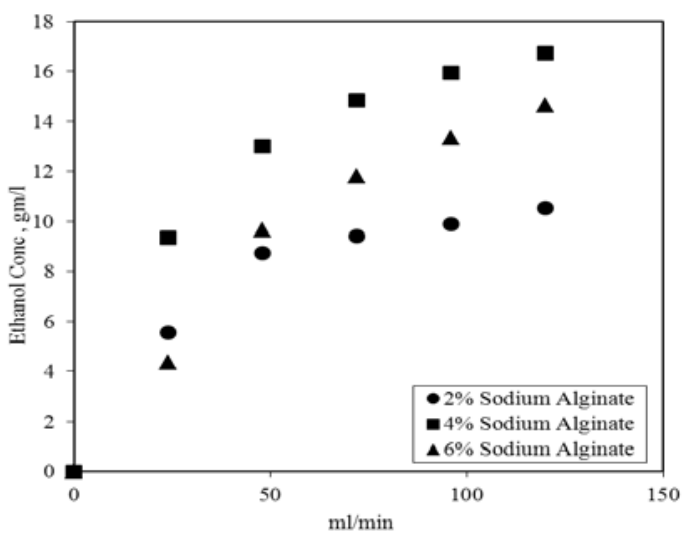

Fig 6 comparision of ethanol production with sodium alginate concentration conc. Beads in batch reactor.

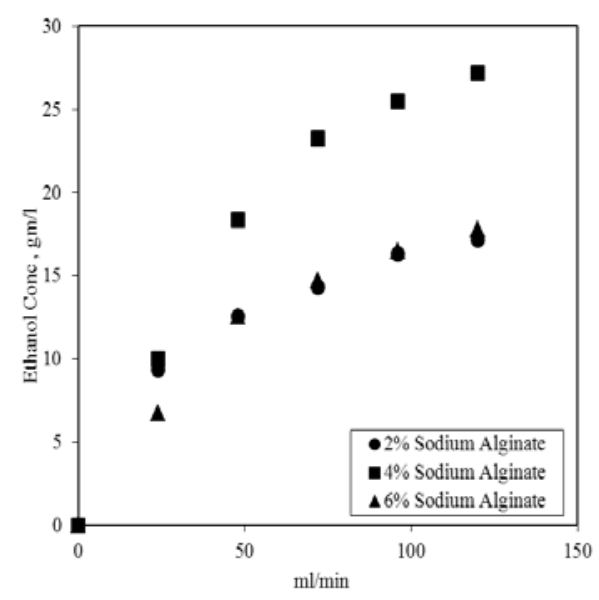

Fig 7comparision of ethanol production with sodium alginate concentration conc. Beads in packed bed reactors.

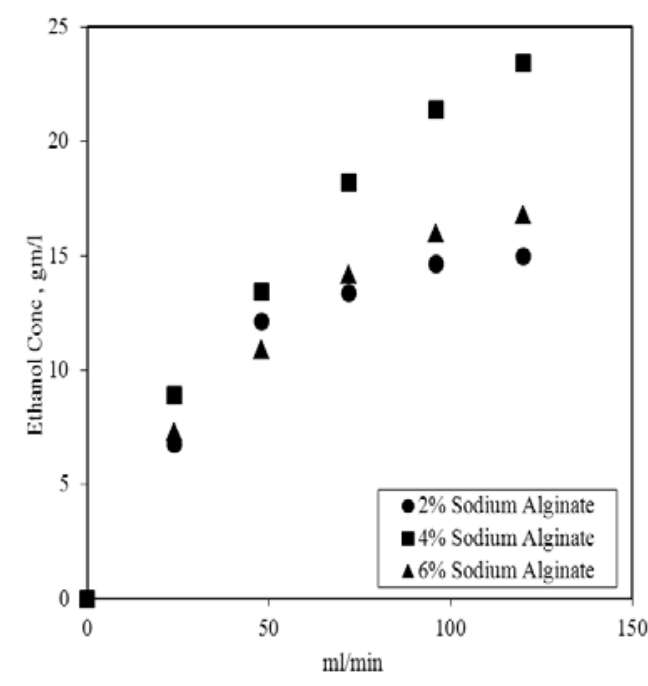

Fig 8comparision of ethanol production with sodium alginate concentration conc. Beads in packed bed bio-reactors. 


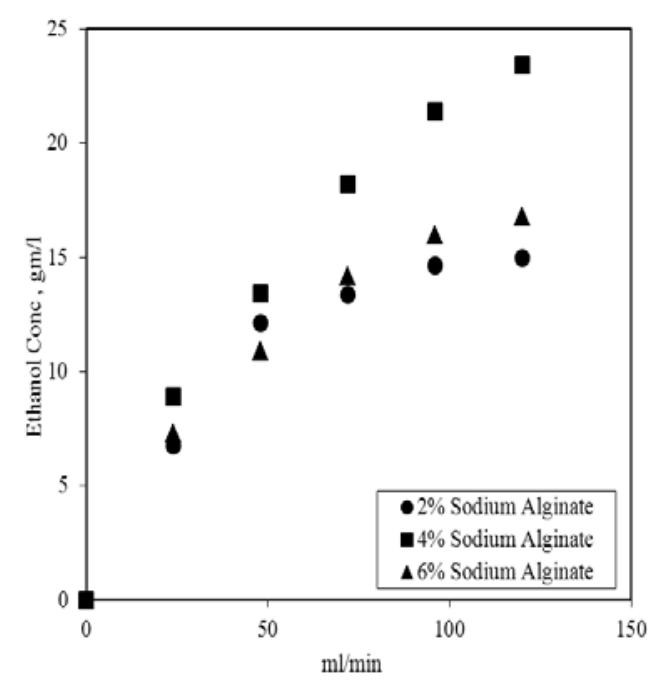

Figure 8comparision of ethanol production with sodium alginate concentration conc. Beads in packed bed bio-reactors.

Figure 3 compares the production of ethanol in three reactor setups with $2 \%$ sodium alginate yeast immobilized beads. Maximum amount of glucose was converted during first $48 \mathrm{hrs}$ with ethanol concentration as $8.75 \mathrm{gm} / \mathrm{l}$ and reaching a maximum concentration of $10.5 \mathrm{gm} / \mathrm{l}$ after $120 \mathrm{hrs}$ in Batch reactor. From the graph, one can observe that the change of bioethanol concentration from 0 hrs to $48 \mathrm{hrs}$ was maximum, from $48 \mathrm{hrs}$ to $120 \mathrm{hrs}$ the increase in concentration or conversion of glucose to ethanol is low in batch reactor. While, the production of ethanol is gradual from 0 hrs to 120 hrs in packed, fluidized bed bio-reactor with a maximum concentration of 17.2 and $15 \mathrm{gm} / \mathrm{l}$ respectively. This is due to most of the glucose is in direct contact with yeast immobilized beads instantaneously in batch reactor while in the packed and fluidized beds the glucose is in circulation. $4 \%$ sodium alginate immobilized yeast beads also shown that similar behavior with all three reactors and can be seen from Figure 4 . While $6 \%$ sodium alginate immobilized yeast beads in batch reactor shown slight variation that change in concentration was gradual and shown in figure 5. Probably the higher concentration sodium alginate immobilized yeast beads were hard, rigid and may lead the diffusion of reactant and product will be less (Goksungur and Zorlu (2009), Widjaja et al. (2010)). The maximum Ethanol concentration will be achieved in packed bed reactor than other two reactors and can be seen in figures 3-5. (Sitton and Gaddy (1980)). Conversions in fluidized bed reactors were better than batch reactor (Gilson and Thomas (1995)).
Effect of sodium alginate concentration for preparation of yeast immobilized sodium alginate beads were shown in figure in 6 for batch reactor. $4 \%$ sodium alginate concentration was shown better performance and achieved $16.7 \mathrm{~g} / \mathrm{l}$ bioethanol concentration in 120 hrs. Similar observations were made in (Gilson and Thomas (1995) \& Goksungur and Zorlu (2009)). The physical appearance of lower concentration sodium alginate were like a fluffy and soft gels, easily breakable beads were formed while the intermediate concentration beads were as stable, hard enough to stand and flexible. Probably the stable and flexible beads gave better performance than other concentration beads. In general high concentration ( $6 \%$ sodium alginate) sodium alginate beads are rigid and diffusional problems may encounter (Najafpour, et al. (2004)). Figure 7,8 show the similar behavior of $4 \%$ sodium alginate made beads shown better performance than $2 \%$ and $6 \%$ sodium alginate beads for packed and fluidized bed bio-reactors.

\section{CONCLUSIONS}

The bio-ethanol production in batch, packed bed, fluidized bed bio-reactors were successfully carried out with yeast immobilized, $2 \%, 4 \%, 6 \%$ sodium alginate concentration. Sterilized $8 \%$ glucose solution was used as feed solution. The glucose concentration gradually decreased with time and bio-ethanol gradually increased with time for batch reactor. The conversion is maximum during $48 \mathrm{hrs}$ period in batch reactor than 48 to $120 \mathrm{hrs}$ while other two reactors shown gradual increase in conversion of glucose or formation of bio-ethanol. The maximum conversion was achieved in packed bed reactor after $120 \mathrm{hrs}$ with 17.2, 27.2, $17.8 \mathrm{gm} / \mathrm{l}$ for $2 \%, 4 \%, 6 \%$ sodium alginate beads respectively. $4 \%$ sodium alginate beads shown better performance than $2 \%, 6 \%$ sodium alginate beads in batch, packed, fluidized bed bio-reactors.

\section{ACKNOWLEDGEMENTS}

The authors gratefully acknowledge the support of the Manipal University, Manipal for providing the financial support and facilities for equipment purchase and conducting the experiments. 


\section{REFERENCES}

[1] Bangrak, P., Limtong, S., and Phisalaphong, M. (2009). Continuous ethanol production using immobilized yeast cells entrapped in loofa reinforced alginate carriers, Braz. Jr. of Microbiology, 42, 676-684.

[2] Chuichulcherm, S. (2005). Design and start-up of a fluidized bed bioreactor for ethanol fermentation, http://fervaap.kku.ac.th/conference/images /Conference2005/FerVAAP2005 Abs.pdf.

[3] Das, A., and Krishna, B.S.V.S.R. (2014). Hydrodynamics of Fluidized Bed Reactor for Ethanol production, accepted for presenting paper in ICGTEPC, NIT, Trichy, India.

[4] Ghasem, N., Younessi, H, Syahidah, K., and Ismail, K.U. (2004). "Ethanol Fermentation in Immobilized cell reactor using Saccharomyces cerevisie, Bioresource Technology", 92, 251-260.

[5] Gilson, C. D., and Thomas, A. (1995). Ethanol production by alginate immobilised yeast in a fluidised bed bioreactor. J. Chem. Technol. Biotechnol. 62, 38-45.

[6] Goksungur, Y., and Zorlu, N., (2009). Production of Ethanol from beet molasses by a Ca-alginate immobilized yeast cell in packed bed bioreactor, Turk J. Biol, 25, 265-275.

[7] Hossain, S.K.M., Anantharaman, N., and Das, M. (2009). Bioethanol fermentation from untreated and pretreated lignocellulosic wheat straw using fungi fusarium oxysporum", Indian Journal of Chemical Technology, 19, 63-70.

[8] Mariam, I., Manzoor, K., Ali, S., and Haq, K.U. (2009). Enhance production of ethanol from free and immobilized Saccharomyces cerevisiae under stationary culture, Pak. J. Bot., 41(2), 821833.

[9] Marin, P., Alklay, D., Guerrero, L., Chamy, R., and Schiappacasse, M. C. (1999). Design and startup of an anaerobic fluidized bed reactor, Wat.SciTech., 40(8), 63-70.
[10] Najafpour, G., Younessi, H., Syahidah, K.U., and Ismail, K.U., (2004). Ethanol Fermentation in Immobilized packed bed Reactor using Saccharomyces cerevisie, Bioresource Technology, 92, 251-260.

[11] Phoowit, B., Limtong, S., and Phisalaphong, M., (2009). "Continuous ethanol production using immobilized yeast cells entrapped in loofa reinforced alginate carriers", Brazillian Journal of Microbiology, 42, 676-684

[12] Rakin, M., Mojovic, L., Nikolic, S., Vukasinovic, M., and Nedovic, V., (2009). Bioethanol production by immobilized Saccharomyces cerevisie var. ellipsoideus cells, African Jr. of Biotech., 8(3), 464-471.

[13] Selvaraj, M., and Krishna, B.S.V.S.R., (2012). Effect of Sodium Alginate Concentration on Size of Yeast Immobilized Particle and on Production of Bio-ethanol in a Packed-Bed Fermenter, J. Energy, Environment \& Carbon Credits, 2(3) 1-6.

[14] Sitton, O. C., and Gaddy, J. L. (1980). Ethanol production in an immobilized-cell reactor. Biotechnol. Bioeng. 22: 1735-1748

[15] Verbelen, P.J., De-Schutter, D.P., Delvaux, F., Verstrepen, K.J., and Delvaux, F.R. (2009). Immobilized yeast cell systems for Continuous fermentation applications, Biotechnol Lett, 28, 1515-1525.

[16] Widjaja, T., Altway, S. A., and Gunawan,S. (2010). Ethanol production from molasses using immobilized cells Ca-Alginate and KCarrageenan by mutation Zymomonas mobilis in a packed bed bireactor, International Journal of Academic Research. 2(6), 30-34.

[17] Zain, M.M., Kofli, N.T., and Yahya, S.R.S., (2009). Bioethanol production by calcium alginate immobilized ST1 yeast system: Effects of size of beads, ratio and concentration", IIUM Engineering Journal, 12(4),124-132. 